\title{
Triage and vital signs in a population discharged from and readmitted to the ED
}

\author{
Ida Helsø $\varnothing^{1}$, Helle Ipsen², Claus Heinecke ${ }^{3}$, Hanne Jørsboe ${ }^{2^{*}}$ \\ From Proceedings of the 5th Danish Emergency Medicine Conference \\ Aarhus, Denmark. 18-19 April 2013
}

\section{Background}

In our community hospital about $20 \%$ of the patients are readmitted within 30 days to the emergency room, where clinical effectiveness and patient safety depend on the triage process including observation of vital signs. Therefore, the study was performed to describe this population and to compare the triage score and vital signs at the first contact and at readmission.

\section{Methods}

Patients were identified from a national database and evaluated through an audit of electronic patient files with registration of the following criteria; triage-level, vital signs, medical problems and diagnosis, supplemented with the vital signs monitored the last day before discharge from the first hospitalization. The vital signs were summarized to a standardized score called BOS. The triage system is a 5 point-scale in colours, where 1 compared to "red" resuscitation. Data were evaluated with a Mann-Whitney non-parametric statistic for paired data.

\section{Results}

A sample of 50 cases were included (26 F, 24 M), mean age 57 years (21-92) of which $64 \%$ of the patients had co-morbidity. Most of the patients were admitted with symptoms of abdominal pain (20\%), dyspnoea (14\%) and alcohol related disease (10\%). At readmission, 58\% patients had related symptoms. The average triage score at the primarily contact were urgent (mean: $3(1-4)$ ) and BOS score $1(0-5)$, which was reduced through stabilization to $0(0-3)(\mathrm{p}<0.05)$. At readmission, the triage score was $3(2-4)$ and BOS level was increased to $1(0-5) .22 \%$ of the patients evaluated by triage had a higher degree

\footnotetext{
* Correspondence: hbjo@regionsjaelland.dk

${ }^{2}$ Emergency Department, Nykobing F Hospital, Denmark

Full list of author information is available at the end of the article
}

of acuity compared to the first contact, supported by $33 \%$ of the patients were evaluated worsened by vital signs (BOS).

\section{Conclusion}

These data suggest a relative young population is readmitted to the ED compared to international studies. A part of these patients with a high degree of co- morbidity, were evaluated urgent by triage and BOS at readmission, despite stabilization before discharge from the first hospitalization. Further audit will be extended to a larger population.

\section{Authors' details}

${ }^{1}$ Medical Department, Nykobing F Hospital, Denmark. 'Emergency Department, Nykobing F Hospital, Denmark. ${ }^{3}$ Department of Quality Improvement, Nykobing F Hospital, Denmark.

Published: 9 September 2013

doi:10.1186/1757-7241-21-S2-A10

Cite this article as: Hels $\varnothing$ et al:: Triage and vital signs in a population discharged from and readmitted to the ED. Scandinavian Journal of

Trauma, Resuscitation and Emergency Medicine 2013 21(Suppl 2):A10.

Submit your next manuscript to BioMed Central and take full advantage of:

- Convenient online submission

- Thorough peer review

- No space constraints or color figure charges

- Immediate publication on acceptance

- Inclusion in PubMed, CAS, Scopus and Google Scholar

- Research which is freely available for redistribution

Submit your manuscript at www.biomedcentral.com/submit

\section{Biomed Central}

(c) 2013 Helsø et al; licensee BioMed Central Ltd. This is an Open Access article distributed under the terms of the Creative Commons Attribution License (http://creativecommons.org/licenses/by/2.0), which permits unrestricted use, distribution, and reproduction in any medium, provided the original work is properly cited. 